\title{
POLITICAL ECONOMY OF SCIENCE, TECHNOLOGY AND INNOVATION DIPLOMACY OF THE PEOPLE'S REPUBLIC OF CHINA
}

\author{
Ramnath Reghunadhan \\ Research Scholar, \\ Department of Humanities and Social Sciences, \\ Indian Institute of Technology Madras. \\ Email: vrramnath@gmail.com
}

Presented at:

American Political Science Association Annual Meeting

Do not cite without the author's permission

Seattle, Washington,

3 October 2021 


\begin{abstract}
:
In an increasingly multipolar but 'glocalised' world, a country's scientific and technological know-how determines its socioeconomic position and strategic disposition, especially related to science, technology and innovation (STI). The STI diplomacy of the People's Republic of China (PRC) developed within a broader political, social and economic environment, which is inherently different from that of Europe and the US. This has had influences from sociocultural, economic and ideational transactions in PRC. The emergence of the 'new developmental state', particularly with the rise of digital systems interconnecting and interlinking the PRC and the World. This has accelerated and transformed the emergence of "variegated forms of capitalism' in PRC. The institutionalization of cyber-physical systems and the economy has been linked to the transitionary disruptions happening with respect to the modes of production, fetishism and accumulation of capital. Currently, PRC is emerging as a major stakeholder in global STI diplomacy, especially with an increased focus on emergent technologies like the Internet of Things (IoT) and artificial intelligence (AI). It is evident in the recent policies and strategies, that have emerged, from PRC and the Belt and Road Initiative (BRI). Further, the political economy of Chinese foreign policy in acting as a key driver for institutionalizing STI in (likeminded) trading partners will be addressed and analyzed in considerable depth in the proposed study. A mixed-method approach has been undertaken, utilizing both qualitative and quantitative approaches to provide a systemic understanding.
\end{abstract}

Keywords: PRC, STI, diplomacy, BRI, developmental state 


\section{Introduction}

In an increasingly multipolar but 'glocalised' world, a country's scientific and technological know-how determines its socioeconomic position and strategic disposition, especially related to science, technology and innovation (STI). Unlike earlier periods, the question of West-originating modern science became introduced, accepted, institutionalized and disseminated, especially with the support of the Chinese State for the first time in its civilizational history (Elman, 2005a; 2005b). The foundation and institutionalization of modern-day science, technology and innovation (STI) in China began in the mid-20 $20^{\text {th }}$ century under the leadership of the Communist Party of China (CPC) (Amsden, 1989; Appelbaum et al., 2018). This was aimed at achieving high and sustainable industrial growth and the promotion of manufacturingled economic activities. The frequent conflicts, the historical baggage of aggression with several countries, and other domestic and social backwardness led to a clarion call by the CPC's political elites to focus on STI-related investment activities within the PRC (Wei, 1984). The STI diplomacy of the People's Republic of China (PRC) developed within a broader political, social and economic environment, which is inherently different from that of Europe and the US. This has had influences from sociocultural, economic and ideational transactions in PRC.

This paper explicates how all these have affected and transformed China's STI diplomacy in its focus on BRI. An in-depth study and analysis of initiatives for inducing and spurring innovation and evaluating impacts, influences, and implications in various fields. The institutionalization of cyber-physical systems and the economy has been (but) linked to the transitionary disruptions happening with respect to the modes of production, fetishism and accumulation of capital. Currently, PRC is emerging as a major stakeholder in global STI diplomacy, especially with an increased focus on emergent technologies like the Internet of Things (IoT) and artificial intelligence (AI). It is evident in the recent policies and strategies from PRC and the Belt and Road Initiative (BRI). Further, the political economy of Chinese foreign policy in acting as a key driver for institutionalizing STI in (like-minded) trading partners within BRI will be addressed and analyzed in considerable depth in the proposed study. 


\section{Data and Methodology}

A mixed-method approach has been undertaken, utilizing both qualitative and quantitative approaches to provide a systemic understanding. The research balances the use of discursive methods (pairing documentary and archival research, including digital data archives) with quantitative tools of empirical research (empirical data collection through disbursal of (online and field) survey questionnaire among an identified sample population, i.e., preventing sample bias. The choice of methods emphasizes the mixedmethods approach, wherein qualitative and quantitative approaches are undertaken for further analysis. Qualitative case studies of legal disputes between foreign and Chinese firms in PRC, particularly related to intellectual property theft and technology transfer, would be an integral part of this approach.

\section{Belt and Road Initiative (BRI): An Introduction}

The BRI is arguably one of the biggest international connectivity projects in the $21^{\text {st }}$ century, one of the biggest and expensive projects during the human civilizational period, comprising more than 60 per cent of the world population. It includes projects like roads, railways, energy projects, free zones, and other infrastructural investment projects connecting numerous countries across various continents with China as the focal point. It has been construed as an initiative that many consider having confirmed the intention, enhancement, intensification and distension of China's activities across the world. The Chinese position on the BRI emphasizes what President Xi Jinping considers for PRC's "Belt and Road Initiative on the basis of the Five Principles of Peaceful Co-existence" (Xi, 2017; MFA China 2019). It has been categorized as an institutionalization of a massive trade network and a political vision. This has been evident from Xi's first speech on BRI at Kazakhstan (in 2013) and thereafter (Al Jazeera English, 2021; MFA China, 2013).

BRI is broadly categorized as comprising five connectivities or links, viz. e. viz., policy coordination, infrastructure building, unimpeded trade, financial integration, and people-to-people exchanges. Numerous countries see this as an opportunity, while other major powers see this as a threat. This entails the Chinese initiative to entail STI across the countries collaborating as part of the BRI. But many Western powers, mainly led 
by the US, have brought concerns, announcing alternative plans and initiatives against what they categorize as the Rise of China. In April 2019, the Center for a New American Security (CNAS) brought out a report titled Grading China's Belt and Road entailed issues in relation to BRI, wherein it opines that:

[The BRI] is in part a propaganda effort to project the inevitability of China's global ascent. Since Xi's political status is intertwined with the BRI prospects, one if fails could cost him complete control over the party. Since BRI has been embedded in the CCP's Constitution, again abandonment is not politically viable (Kliman et al. 2019).

BRI is considered an internal and external driver, overall undertaking a holistic approach for engaging with various initiatives. It can provide sustained growth to the Chinese economy, a loosely connected continental economy that has also been integrated into the $13^{\text {th }}$ Five Year Plan and $14^{\text {th }}$ Five Year Plan. Since 2015, it has been linked with various initiatives like Made in China 2025, Internet Plus etc. Further, the "going global" strategy, which has been funded by the EXIM Bank and China Development Bank, to help Chinese state-owned enterprises (SoEs) access new markets, regional e-commerce and cross-border transactions (in RMB), reduce the economic development gap within China between coastal and landlocked/underdeveloped provinces, energy security issues directly linked to the Malacca Dilemma, and the threats from Blue Water Navy of the US. Through BRI, China intends to "expand its circle of friends" (Rolland, 2019; Lei, 2017) and influence various actors and stakeholders against potential challenges and threats from gunboat diplomacy, coercive military power, and counter-encirclement strategies of major powers. This is also a direct contradiction to a (pre-existent unipolar) US-led world order and hegemony and inherently tilts towards what many scholars consider to be a shift towards a balance of power system.

The first shift towards the BRI system began with the Asian Development Bank Report of 2009, which estimated the need to have an investment ranging from one to four trillion USD for 2010-20 (ADB, 2021). This, coupled with the impact and aftereffects of the 2008 Global Financial Crisis, aggravated the need for global trade 
and economic restructuring (Reghunadhan, 2018). This had a huge influence on the speeches by President Xi Jinping at Astana (in September 2013) and at Kazakhstan (in November 2014). During the latter speech, the announcement for the creation and institutionalization of BRI through the creation of a Silk Road Fund and other related mechanisms has been underway (Kembayev, 2020; Xi, 2013; Rolland, 2019). In June 2015, the China Development Bank announced funding for 900 projects under BRI, estimated to be around 900 billion USD. In January 2016, the Asian Infrastructure Investment Bank, in partnership with the World Bank and the Asian Development Bank (ADB), announced capital of 100 billion USD (Chinese share of 28 per cent) to fund various projects in BRI-related projects (Lockhart, 2017).

In May 2017, in the Belt and Road Forum (BRF), Ning Jizhe, the vice-chairman of National Development and Reform Commission (NDRC), claimed that Chinese investments would be between 600 billion and 800 billion USD, with an estimated annual investment of about 120 to 160 billion USD (The Economic Times, 2017). Additionally, President Xi also pledged Xi pledged an additional 14.5 billion USD for Silk Road Fund, about 56 billion USD in loans, and around nine billion USD in aid to developing countries and international bodies in BRI. In October 2017, James Mattis, the US Secretary of Defence, stated that "we can isolate some of the broader areas where we have divergence and find China potentially a helpful partner in Afghanistan, particularly with the development funds that are going to be necessary", mainly because the US Administration's ability to fund future projects is in decline (US Senate Committee on Armed Services 2017, pp. 62-63). According to Mattis, the "relationship with China is critical to the administration's regional strategy" (pp. 72-85) with "vital national interests inside of South Asia" (p. 87).

In January 2018, the China Development Bank committed about 250 billion USD in loans to BRI countries. However, there has been various funding and investment challenges as well. The Asian Development Bank (ADB) report estimated a funding gap for infrastructure projects in Asia, 1.7 trillion USD annually, and 26 trillion USD for the next decade. Incidentally, though budget estimates for BRI are around one trillion USD, no official figures, announcements and/or reports by Chinese administration and officials (Rolland 2019), this is entailed through major policy 
decisions, guidelines, white papers and statements related to BRI-related projects, initiatives and mechanisms, either domestically, regionally and/or internationally. ${ }^{1}$

However, in August 2018, Mahathir bin Mohamad, the Malaysian PM, opined that "there is a new version of colonialism happening because poor countries are unable to compete with rich countries" (Hornby, 2018). The Chinese position in this case, wherein Beijing views the debt problem in countries part of the BRI as historically existent and has been mainly due to the defects in economic structure and systemic crisis at the domestic level. Moreover, only recently has China started investing, particularly under the BRI, while investors related to the West and other international organizations have been "major creditors" for a long time and are even responsible for many of the inherent crises occurring in a recurring manner (Singh, 2019; Du, 2021).

On the fifth anniversary of the BRI, President Xi announced a "new phase" of the program to rectify and remove investment limitations. There has been an encouragement to focus more on "high-quality" investments that are smaller in scale. According to $\mathrm{Xi}$, "broad brushstrokes" had been made in the first phase, and now should be more on "high-quality" investments that are smaller-scale, whereby "fine brushwork" should be done as well. Interestingly, smaller projects have fewer issues with financial sustainability and corruption, and new state institutions like the China International Development Cooperation Agency (CIDCA) have been launched to provide supervision to mitigate the risks economically, environmentally and politically. BRI is involved in massive projects with possibilities to connect using rail lines from Chinese cities to Singapore. The project is to build a massive Shenzhen-like port city in Tanzania's town of Bagamoyo. Beijing will reduce the volume of projects, more controllable and viable. A major focus of the BRI in the next phase is the telecommunications infrastructure, which will enable communication, internet connectivity, and cellular infrastructure. China is building or operating telecommunications infrastructure in Myanmar, Kyrgyzstan, Nepal, Bangladesh, Mexico, Kenya and others (pp. 24-25).

\footnotetext{
${ }^{1}$ It was very evident during the $2015-18$ period.
} 
The prominent political steering agencies that focus on BRI-related activities include the Ministry of Commerce (MOFCOM), Ministry of Culture (MoC), Ministry of Foreign Affairs (MFA China), the National Development and Reform Commission (NDRC), and the State International Development Cooperation Agency (SIDCA). There are numerous international, intergovernmental, regional and multilateral cooperation mechanisms that engage in BRI-related activities. This includes the Asia Cooperation Dialogue (ACD), Asia-Europe Meeting (ASEM), Asia-Pacific Economic Cooperation (APEC), Association of Southeast Asian Nations (ASEAN), Central Asia Regional Economic Cooperation (CAREC), China-Arab States Cooperation Forum (CASCF), China-Gulf Cooperation Council Strategic Dialogue, Conference on Interaction and Confidence-Building Measures in Asia (CICA), Greater Mekong Subregion Economic Cooperation (GMS), and the Shanghai Cooperation Organization (SCO). The major funding institutions for BRI include the Afro-Asian Economic Council (AAEC), Asian Infrastructure Investment Bank (AIIB), China-CEE Fund, China Investment Corporation (CIC), China Development Bank (CDB), ChinaEurasian Economic Cooperation Fund (CEF), Export-Import Bank of China (EXIM), New Development Bank (NDB), Russia-China Investment Fund (RCIF), Silk Road Fund (SRF), and State Administration of Foreign Exchange (SAFE).

\section{Developmental State in the People's Republic of China}

The emergence of the 'new developmental state', particularly with the rise of a digitally connected world, is interconnecting and interlinking the PRC into an era of digital globalization. It was prioritized in China and was initially developed by scholars like Johnson (1982), Amsden (1989), and Wade (2000) provide extensive works on the utilization of the concept of the developmental state, wherein the focus is given to rapid economic development and industrialization. This has accelerated and transformed the emergence of 'variegated forms of capitalism' in PRC. The concept of a developmental state emerged as prioritization towards achieving overall economic growth and development rapidly. This is achieved through the implementation and utilization of policies. It was put forward in the context of implementation within East Asian countries. Interestingly, this was evident in focus towards rapid economic and industrial development and related strategies. 
The focus of China towards what scholars like Naughton (2007) characterize as heavy industrialization took place widely within the command economy, while Japan and South Korea gave a greater emphasis on this. Interestingly, this was in line with the 'flying geese model' adopted within the East Asian region, thus creating, the conditions for, the East Asian model of state-led development. Scholars like Pekkanen (2004) and Wong (2004) have contributed to this understanding in public policy, social welfare, and restructuring in the industrial sector. Additionally, the Chinese model categorically entails importing the 'flying geese model' into the Chinese context.

According to White (1988), PRC does provide for success in the lens of Listian political economy, one where development is agreed to "as a national endeavour guided by a strong and pervasive state" (p. 26). According to List, political economy "limits its teaching to the inquiry [on] how a given nation can obtain... prosperity, civilization and power." Before the idea of free trade/ market became a prominent narrative across the West, the "practice of political economy" was under the ambit of the "State officials, administrators, and authors who wrote about matters of administration occupied themselves exclusively with agriculture, manufactures, commerce, and navigation of those countries to which they belonged." According to List, it predates the idea of universal free trade as expounded by Francois Quesnay, Adam Smith and others, all of whom are the adherents of the cosmopolitical economy (pp. 97-108).

It was prioritized in China and was initially developed by scholars like Gerschenkron (1962), Johnson (1982), Amsden (1989) and Wade (2000), Woo (1991), Fields (1995) and Woo-Cummings (1999) with extensive works on the utilization of the concept and institutionalization of the developmental state. White (1991) specifically analyses the economic programme that created a "new form of [the] developmental state in China," as well as the interlinkages between the State and its economy. According to White, the urban government in China provided a huge impetus "towards financial decentralization, [in providing] institutional changes in district administration" and, more importantly, in streamlining the administrative aspects of the "local government and the urban economy." This resulted in what is considered to be a "dualistic" state, containing "elements of both old and new forms of the developmental state." The "reformist innovations in industrial administration," particularly related to increases in "the financial and managerial autonomy of enterprises", threatened and later on transformed the old institutional frameworks within the State (pp. 149-165). 
According to Kohli (2004), developmental states are those "states with cohesive structures and strong commitments to growth-conducive policies (p. 10). The focus is given to rapid economic development and industrialization. Calder (1993) defines the developmental state as emphasizing state intervention and strategic resource allocation (p. 6). Antons (2003) provides effective enforcement, creation, and protection of statutory regimes encompassing private property rights. This impacted credit allocation, foreign investment, and tax administration (pp. 76-83). Meanwhile, Ong (2006) emphasizes how the developmental state narrative became a prominent aspect of China's national economy. She argued how the post-reform period saw China successfully imbibe 'necessary parts' of the neo-classical model of economic growth that is often considered the dominion of Western and democratic countries. Ong argues that the "state strategies- informed by neoliberal logic-that produce condition for [the] possibility for proliferating... cross-border networks" (Ong, 2006: p. 98).

Initially, from being considered a weak developmental state to what China has achieved so far, many have been often considered a form of hybrid liberalism or ordoliberalism, which have led to the conceptualization of socialism with Chinese characteristics. Sachs and Woo (1991) provide detailed aspects of underdevelopment, large and flexible rural economy, and second-stage reforms. In 2003, the transition process was advanced, but there persisted gaps in institutional mechanisms, issues of weak legal accountability, overly dominant influence of State, increasing NPAs, weak fiscal relations between Centre and states, largely underdeveloped local fiscal capacities, and shock and related issues related to the "smash the iron rice bowl" (pp. 101-145).

Interestingly, this is in line with ordoliberalism or hybrid liberalism, as entailed by many in the case of China. It emphasized that the state provides the legal framework and protection for the market (through the disarticulation policy) and thereby prevents market disruptions, an idea developed by the former German Chancellor Ludwig Erhad. The disengagement of the coastal areas in the Southern part of China and its development in (the form of) special economic zones (SEZ), namely Shenzhen, Xiamen, Shantou, Zhuhai, contributed to a variant developmental state in the PRC. This interestingly created what scholars like Chu (2009) and Ong (2006) describe as State Neoliberalism or State capitalism. Meanwhile, White (1984) explains the various 
characteristics of the developmental state: "social basis, institutional character, modes of operation and developmental potential (pp. 98-104).

Further, various models or theories like the general theory and institutional actors and stakeholders have been entailed in terms of the developmental state. As scholars like Wong (2004) argue, the orientation of the developmental state is not static but dynamic or organic in a way that there is a continuous evolution in countries like Japan, South Korea, China and Taiwan. This was more evident in the postwar period when China and other countries have had implications related to the relational and existential aspects and linkages with sovereignty and economic development. Further, the challenges and pressures for these countries were increasingly variant due to the various socioeconomic and political divergences. But overall, it did develop a postwar East Asian developmental state model, which scholars like Skocpol (1985) state, was initially dominated by the statist paradigm. This was evident in the ' 80 s and ' 90 s, wherein the concepts of state capacity and state autonomy were reinforced, becoming part of the intellectual vernacular.

Ong examines the inherent aspects that entail China's activities that "create the political spaces and conditions of variegated sovereignty aligned on the axis of trade, industrialization and knowledge exchange" (Ong, 2006: p. 98). Reghunadhan (2018) examines how this challenges the inherently assumed notion that "economic and political forms of integration develop in different spheres" (pp. 24-25). China became a hub for low-cost manufacturing by prominent companies and brands. The State allowed industrial companies preference in foreign investment. Unlike the earlier forms of neoliberal conceptualization where the Smithian 'Invisible Hand' helped the market self-correct itself, the Chinese State became the 'Visible Hand' to correct the market and retain the activities that would lead the economy into development path. Concomitantly, in the 21 st century, China overtook every country worldwide in terms of GDP (Reghunadhan, 2018).

\section{Political Economy of PRC's STI Diplomacy}

Kohli (2004) has ascertained that China's STI policies are very much dependent upon the success in fostering "globally competitive domestic firms in key industries and 
technologies." This is very evident in China's catching-up in relation to STI-related technologies and the impact on its economy. The political economy of STI in PRC, according to White (1988), is similar in line with the Listian understanding of political economy (p. 1). List (1841) has written extensively on the "practice of political economy" in his work The National System of Political Economy published in 1841 (p. 97). White (1988) details how the "states have played a strategic role in taming domestic and international market forces" and helped harness the "national economic interest" (p. 1). Thus, the ideational understanding of developmentalism and interventionist state are intertwined and "inseparable" (White, 1988: pp. 1-2). This was evident in the early periods of the PRC but in the form of an "overly pervasive pattern of directive state intervention" (p. 18).

The PRC's STI-related policies and implementation strategies have always focused on this, which is why S\&T has been part of the four modernization strategies since the 1960s. Wong (2004) has focused on the orientation of the developmental state, which is considered more dynamic and organic than Skocpol (1985) considers static. This is evident in the transformative contextualization of state sovereignty and economic nationalism to cyber sovereignty and techno-nationalism. (Appelbaum et al., 2018: pp. 111-113; Kor, 2016; Spence, 2001). Solow (1956), Ray (1998) and Todaro \& Smith (2006) have explained the role and impact of STI on national economies, laying the foundation for a knowledge economy. This has been accepted as an inherent part of sustainable development activities, even at an intergovernmental level.

Solow (1956), for the first time, described technology in terms of the modern-day understanding of STI as the category of the residual. It includes the means of production, including the development of $\mathrm{R} \& \mathrm{D}$, human capital, and institutionalization. This includes advancements through education, technical competence, institutional/organizational restructuring and man-management and production methods. According to Todaro \& Smith (2006), there were initial scholarly developments in academics and politics regarding conceptualization and theorization of the national economy. It did not fully take into consideration the issues concerning the sources of technological changes. It could not explain, what was considered, residual; and failed to capture the relatively huge differences among countries with similar technological capabilities. The introduction of changes in STI became a major 
factor in calculating the economic growth and development of a country (Nelson, 1959; Romer, 1990; 2000).

Globally, additional ways of furthering STI activities, as a relatively unassailable part of the indicators of growth and development in countries, were undertaken, mainly by neoclassical economists ${ }^{2}$ as well as the policies of the administration of the US (Reaganism) $)^{3}$, which dominated the global narrative (Helpman, 1998; Aghion, David $\&$ Foray, 2008). At the end of the $20^{\text {th }}$ century, the economic impact of STI policies was ingrained and integrated into developed countries' structures and accepted in most developing countries. This led to increased support through government spending and furthering of STI. Judd (1985) has researched the impact of patents and its functionalities having a multiplier-positive impact on the country's economic growth and development. The model used by Judd was developed in line with Dixit \& Stiglitz (1980) and Spence (1976). Dixit \& Stiglitz (1980) focus on monopolistic competition and the issues related to "market solution," which the paper argues are due to three reasons: "distributive justice; external effects and scale economies" (p. 297). Meanwhile, Spence (1976) focuses on issues related to product selection due to "fixed costs and monopolistic competition" (p. 217).

The state's and related institutions' behaviour was understood based on various parameters that considered the behavioural aspect of these actors. The narrative was entailed upon by Arnold Toynbee (1884), Friedrich List (1841), Clairmonte (1959) and Wilson (2014) to provide for what is considered to be economic nationalism. The policies have been largely disruptive towards the market, polarised the centres of power and led to the widespread utilization of tariffs and quotas to protect, what countries considered as, national interest. This was interestingly the model of Germany and the US in the pre-War period and was later adopted in Japan and other East Asian

\footnotetext{
${ }^{2}$ According to neoclassical economists, technology is one of the three driving forces of economic growth. Combined with the other two, labor and capital, the technology according to economists like Robert Solow and Trevor Swan can drive the economic growth. Solow's seminal work, A contribution to the theory of economic growth published in 1956, introduced an empirical understanding of interlinkages between technology and economic growth (Solow, 1956; Banton, 2020).

${ }^{3}$ American President Ronald Reagan believed that technology was very vital for attaining economic superiority, transforming the country into the "factory of the future," and catching-up with then technological leaders like Europe and Japan. According to him, this was very important in boosting "market share and industrial leadership of US industry" (Kennedy, 2003). This was a turning point in American technological and economic superiority during the Cold War, as well as in the later period.
} 
economies. This had a huge effect on growth in these economies, leading to one of the highest collective regional growths in the $20^{\text {th }}$ century.

However, there have been issues associated with the emergence of the 'new developmental state', wherein the role and effectiveness of the Chinese administration, acting as a key driver for institutionalizing and utilizing STI for diplomacy in BRI countries, will be addressed and analyzed in considerable depth by the paper. The political economy of BRI is related to science, technology and innovation projects by China. This includes renewable energy projects, education, satellite communication, health and high-speed rail in countries like Cambodia, Georgia, Indonesia, Kazakhstan, Myanmar, Nigeria, Pakistan, Tajikistan, Thailand, and Uganda. Since 2015, China has been the highest bilateral creditor to African countries, accounting for 13 per cent, three times that of the US (the second-highest creditor). It is more than the next four highest bilateral lenders (the US, France, Saudi Arabia, and the UK) and the second-highest source of Africa's external debt, behind only bondholders, who account for 27 per cent (African Development Bank, 2021: p. 50).

Currently, PRC is emerging as a major stakeholder in global STI diplomacy, especially with an increased focus on emergent technologies like the Internet of Things (IoT) and artificial intelligence (AI). An important direction in this regard is the Digital Silk Road (DSR), which was launched in 2015 as an important facet of the BRI. According to Ghiasy and Krishnamurthy (2021), DSR-related investments in 2018 reached an estimated 79 billion USD and exponentially rose each year. This has been accelerated with the increase in digital (inter-)connectivity, the developments in 5G infrastructure, and the acceleration of global digitalization with the current COVID-19 pandemic (Gyu 2021). Table 1 shows the projects and investments under BRI that are already planned, under construction, completed, and/or operational in the civilian sector under the DSR during 2015-21.

Table 1: Sector-wise projects and investments under the BRI that has been planned, invested, completed and/or operational under the category of the DSR during 2015-21 


\begin{tabular}{|c|c|c|c|c|}
\hline Country & Project/Category & $\begin{array}{c}\text { Estimated/ } \\
\text { Reported } \\
\text { Cost (in USD) }\end{array}$ & $\begin{array}{c}\text { Chinese } \\
\text { Involvement }\end{array}$ & $\begin{array}{c}\text { Investment/ } \\
\text { Planned } \\
\text { Completion/ } \\
\text { Operational/ } \\
\text { Completed }^{\#}\end{array}$ \\
\hline \multirow[t]{2}{*}{ Afghanistan } & $\begin{array}{l}\text { Kashgar (China)- Faizabad } \\
\text { (Afghanistan) optic fiber } \\
\text { line (National Grid) }\end{array}$ & \multirow[t]{2}{*}{50 million } & $\begin{array}{c}\text { F/L/G, BOT, } \\
\text { O\&M, TA }\end{array}$ & \multirow[t]{2}{*}{$2017-21(\mathrm{I})$} \\
\hline & $\begin{array}{l}\text { Telecommunications } \\
\text { Industry }\end{array}$ & & $\begin{array}{c}\text { F/L/G, EPC, } \\
\text { O\&M, TA }\end{array}$ & \\
\hline Angola & $\begin{array}{c}\text { Smart Cities \& Surveillance } \\
\text { systems }\end{array}$ & NA & $\begin{array}{c}\text { EPC, } \\
\text { O\&M, TA }\end{array}$ & $2019-20$ \\
\hline Bahrain & $\begin{array}{c}\text { 5G mobile communications, } \\
\text { digital economy, e- } \\
\text { commerce and big data }\end{array}$ & $\mathrm{MoU}$ & \multirow[t]{3}{*}{$\begin{array}{c}\text { F/L/G, EPC, } \\
\text { TA }\end{array}$} & $\mathrm{MoU}$ \\
\hline \multirow[t]{2}{*}{ Bangladesh } & Telecom/ ICT: Sinomach & 180 million & & $2015(\mathrm{I})$ \\
\hline & $\begin{array}{l}\text { Telecom/ ICT: Zhongxing } \\
\text { Telecommunications } \\
\text { Equipment (ZTE) } \\
\end{array}$ & 150 million & & 2015 (I) \\
\hline \multirow[t]{2}{*}{ Bolivia } & $\begin{array}{c}\text { Telecom/ ICT: China } \\
\text { Aerospace Science and } \\
\text { Technology - Tupac Katari }\end{array}$ & 300 million & \multirow[t]{2}{*}{ EPC, TA } & $2015-16$ \\
\hline & $\begin{array}{c}\text { Smart Cities \& Surveillance } \\
\text { Systems }\end{array}$ & 105 million & & 2019 \\
\hline $\begin{array}{c}\text { Burkina } \\
\text { Faso } \\
\end{array}$ & $\begin{array}{c}\text { Smart Cities \& Surveillance } \\
\text { Systems }\end{array}$ & 94 million & $\begin{array}{c}\text { F/L/G, EPC, } \\
\text { O\&M, TA }\end{array}$ & 2021 \\
\hline Cameroon & Telecom/ ICT & 490 million & $\begin{array}{c}\text { F/L/G, EPC, } \\
\text { TA }\end{array}$ & 2015 \\
\hline Chile & Telecom/ ICT: Huawei & 100 million & EPC, TA & $2019(\mathrm{I})$ \\
\hline Ecuador & \multirow[t]{3}{*}{$\begin{array}{c}\text { Smart Cities \& Surveillance } \\
\text { Systems, ICT }\end{array}$} & 200 million & $\begin{array}{c}\text { F/L/G, EPC, } \\
\text { O\&M, TA }\end{array}$ & 2016 \\
\hline Egypt & & $\begin{array}{l}\text { Agreement } \\
\text { Signed }\end{array}$ & $\begin{array}{c}\text { EPC, } \\
\text { O\&M, TA }\end{array}$ & 2021 \\
\hline Ethiopia & & 2.8 billion & $\begin{array}{c}\text { F/L/G, EPC, } \\
\text { TA }\end{array}$ & 2016-21 (I) \\
\hline Ghana & $\begin{array}{c}\text { Telecom, Smart Cities, } \\
\text { Surveillance Systems }\end{array}$ & 180 million & $\begin{array}{c}\text { F/L/G, EPC, } \\
\text { TA }\end{array}$ & 2020 \\
\hline Guinea & Telecom/ICTs & 240 million & \multirow[t]{3}{*}{ EPC, TA } & 2015 \\
\hline Greece & $\begin{array}{c}\text { Telecom/ICTs: Shanghai } \\
\text { Gongbao, Kai Xin Rong - } \\
\text { Forthnet } \\
\end{array}$ & 560 million & & 2017 (I) \\
\hline Hungary & $\begin{array}{l}\text { Telecom/ICTs: EXIM Bank } \\
\text { - Invitel Group } \\
\end{array}$ & 210 million & & 2017 (I) \\
\hline \multirow[t]{5}{*}{ India } & $\begin{array}{c}\text { Baidu India Internet Private } \\
\text { Limited } \\
\end{array}$ & 544,000 & $\mathrm{~F} / \mathrm{L} / \mathrm{G}$ & 2016 \\
\hline & $\begin{array}{c}\text { Bharti Airtel Pre-5G } \\
\text { Partnership } \\
\end{array}$ & NA & Suspended & Suspended \\
\hline & Jio Pre-5G Partnership & NA & EPC, TA & Suspended \\
\hline & $\begin{array}{l}\text { E-commerce, mobile } \\
\text { applications }\end{array}$ & 2-3 billion & $\mathrm{F} / \mathrm{L} / \mathrm{G}$ & $2015-20$ \\
\hline & $\begin{array}{c}\text { Vodaphone India Pre-5G } \\
\text { Partnership }\end{array}$ & $50-60$ million & \multirow[t]{3}{*}{ EPC, TA } & Suspended \\
\hline Iran & $\begin{array}{c}\text { Telecom/ ICT/ Surveillance } \\
\text { Technology (Facial } \\
\text { Recognition Program) } \\
\end{array}$ & NA & & 2020 \\
\hline Israel & $\begin{array}{l}\text { Telecom/ICT: Tencent, } \\
\text { Renren - Singualariteam }\end{array}$ & 100 million & & 2015 (I) \\
\hline
\end{tabular}




\begin{tabular}{|c|c|c|c|c|}
\hline & $\begin{array}{c}\text { Telecom/ICT: Huawei } \\
\text { Technologies - Toga } \\
\text { Networks }\end{array}$ & 150 million & & 2016 (I) \\
\hline & $\begin{array}{l}\text { Telecom/ICT: Yinniu } \\
\text { Microelectronics-led } \\
\text { consortium }\end{array}$ & 110 million & & $2020(\mathrm{I})$ \\
\hline \multirow[t]{2}{*}{ Italy } & Telecom/ICT: ZTE & 1.01 billion & & $2016(\mathrm{I})$ \\
\hline & $\begin{array}{l}\text { Telecom/ICT: Huawei } \\
\text { Technologies }\end{array}$ & 1.25 billion & & 2019 (I) \\
\hline Ivory Coast & $\begin{array}{l}\text { Telecom/ICT: China } \\
\text { Communications } \\
\text { Construction }\end{array}$ & 100 million & & 2019 (I) \\
\hline Kazakhstan & $\begin{array}{c}\text { Smart Cities \& Surveillance } \\
\text { Systems }\end{array}$ & NA & & 2019 \\
\hline Kyrgyzstan & $\begin{array}{c}\text { Surveillance Technology \& } \\
\text { Logistics } \\
\text { (Mobile, Internet \& Facial } \\
\text { Recognition Program) }\end{array}$ & 275 million & & $2020-21$ \\
\hline Kenya & $\begin{array}{c}\text { Surveillance Technology } \\
\text { (Mobile \& Internet): Huawei } \\
\text { Technologies }\end{array}$ & 170 million & & $2019(1)$ \\
\hline Laos & $\begin{array}{c}\text { Cloud computing, IoT, } \\
\text { security management } \\
\text { system, Technology and } \\
\text { Innovation Support Center }\end{array}$ & $\begin{array}{c}\text { To be } \\
\text { determined }\end{array}$ & $\begin{array}{c}\text { To be } \\
\text { determined }\end{array}$ & 2021 \\
\hline Malawi & $\begin{array}{c}\text { ICT, 4G Technology } \\
\text { Demonstration Center, agri- } \\
\text { tech }\end{array}$ & NA & EPC, TA & $2015-20$ \\
\hline Malaysia & Smart City project & 900 million & & 2019 \\
\hline \multirow[t]{2}{*}{ Maldives } & IT infrastructure project & 42 million & & 2015 \\
\hline & Telecom/ICT & $\begin{array}{c}\text { To be } \\
\text { determined } \\
\end{array}$ & $\begin{array}{c}\text { To be } \\
\text { determined }\end{array}$ & 2021 \\
\hline Mauritius & $\begin{array}{c}\text { Smart Cities \& Surveillance } \\
\text { Systems }\end{array}$ & $\begin{array}{c}\text { To be } \\
\text { determined }\end{array}$ & $\begin{array}{c}\text { To be } \\
\text { determined }\end{array}$ & 2025 (D) \\
\hline Mongolia & Surveillance Technology & 240,000 & EPC, TA & 2018 \\
\hline Morocco & \multirow[t]{2}{*}{$\begin{array}{c}\text { Smart Cities \& Surveillance } \\
\text { Systems Policing }\end{array}$} & 1 billion & \multirow[t]{2}{*}{$\begin{array}{c}\text { F/L/G, EPC, } \\
\text { TA }\end{array}$} & 2029 \\
\hline \multirow[t]{2}{*}{ Myanmar } & & 1.2 million & & 2021 \\
\hline & Telecom/ ICT & 380 million & \multirow[t]{3}{*}{ EPC, TA } & $2018(\mathrm{I})$ \\
\hline \multirow[t]{2}{*}{ Namibia } & $\begin{array}{c}\text { Smart Cities \& Surveillance } \\
\text { Systems, Policing }\end{array}$ & $\begin{array}{l}12.97 \text { million } \\
\text { USD }\end{array}$ & & $2015-20$ \\
\hline & 3G/4G/5G infrastructure & $\begin{array}{c}\text { To be } \\
\text { determined }\end{array}$ & & 2020 \\
\hline Nepal & $\begin{array}{c}\text { Jilongzhen (China)- } \\
\text { Raduwagadi (Nepal) optical } \\
\text { fibre cables, } \\
\text { Smart Cities, } \\
\text { Telecom/ICT, } \\
\text { Sino-Nepal Joint Research } \\
\text { Centre }\end{array}$ & 170 million & $\begin{array}{c}\text { F/L/G, EPC, } \\
\text { O\&M, TA }\end{array}$ & $2018-19$ \\
\hline Nigeria & $\begin{array}{c}\text { Telecom/ ICT, } \\
\text { Surveillance Technology }\end{array}$ & 328 million & $\begin{array}{c}\text { F/L/G, EPC, } \\
\text { TA }\end{array}$ & 2018 \\
\hline $\begin{array}{c}\text { New } \\
\text { Zealand }\end{array}$ & $\begin{array}{c}\text { Telecom/ICT } \\
\text { 5G: Huawei Technologies }\end{array}$ & 280 million & EPC, TA & 2017 (I) \\
\hline Pakistan & Daraz Group (e-commerce) & $\sim 1$ billion & & $2017-21$ \\
\hline
\end{tabular}




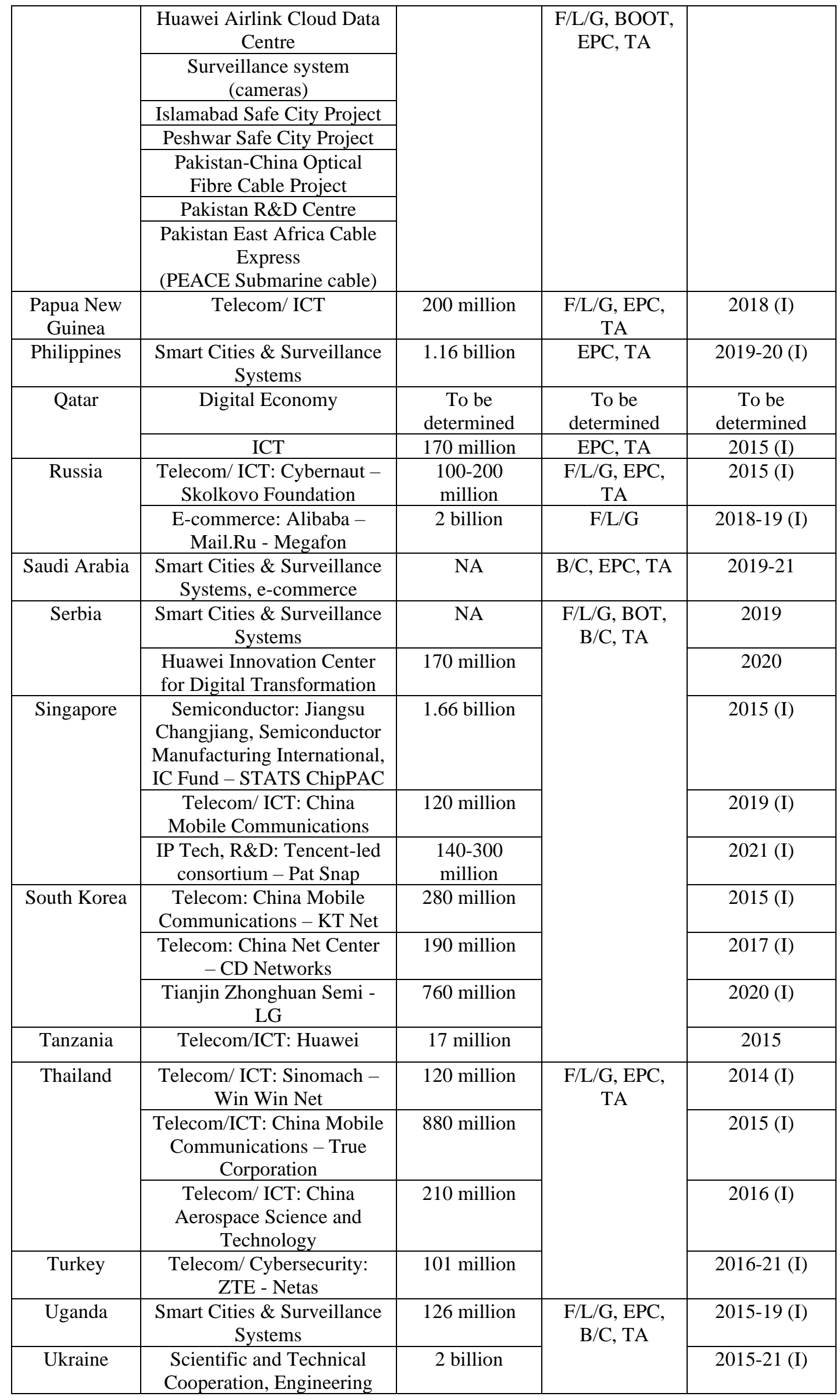




\begin{tabular}{|c|c|c|c|}
\hline \multirow[t]{2}{*}{ UAE } & $\begin{array}{c}\text { Smart Cities \& Surveillance } \\
\text { Systems }\end{array}$ & 100 million & $2018-20(\mathrm{I})$ \\
\hline & $\begin{array}{l}\text { AI Centre of Excellence/ } \\
\text { (Europe, Middle East and } \\
\text { Africa/ EMEA R\&D Lab) }\end{array}$ & 620 million & 2019-20 (I) \\
\hline Uzbekistan & $\begin{array}{c}\text { Smart Cities \& Surveillance } \\
\text { Systems }\end{array}$ & 1 billion & $\begin{array}{c}2019 \\
2023 \\
\text { (Deadline) }\end{array}$ \\
\hline Venezuela & & 70 million & 2016 \\
\hline Vietnam & Telecom/ ICT: Goer Tek & 260 million & $2019(\mathrm{I})$ \\
\hline Zambia & $\begin{array}{c}\text { Telecom, Smart Cities \& } \\
\text { Surveillance Systems }\end{array}$ & 1 billion & 2014-19 (I) \\
\hline Zimbabwe & $\begin{array}{c}\text { Smart Cities \& Surveillance } \\
\text { Systems }\end{array}$ & 71 million & 2018-19 (I) \\
\hline
\end{tabular}

Source: Compiled by the Author. Note: BOT: Build, Operate and Transfer; EPC: Engineering, Procurement and Construction; O\&M: Operation and Maintenance; F/L/G: Funding/Loan/Grants; B/C: Build/Construction; O: Operation; TA: Technical Assistance; (I): Investment; (D): Deadline; NA: Not Available; LoI: Letter of Intent. \#: As of June 2021.

Another issue concerning Chinese projects under BRI is the export of technologies related to surveillance and censorship, which increases the trajectory towards totalitarian and authoritarian norms, systems and values in developing and least developed countries (LDCs). China-based Huawei has helped build a communication network, install video surveillance, data centres and other infrastructure in pockets and regions of the country, smart policing etc., in countries in the South Asia and West Asian and Northern African (WANA) region. The countries in Africa and South America are spending millions and billions of dollars on Chinese equipment regarding telecommunications, broadcasting and surveillance technologies and establishing data and innovation centres that enable effective policing and restrictions. Incidentally, this has increased the authoritarian tendencies of various regimes, most of which are illiberal and undemocratic. The import of facial recognition system has, despite in pros like reducing crime rate and improvements in security and safety of citizens across various nation-states, have been largely inimical to human rights protection and privacy. It has a huge potential to strengthen authoritarianism, increase the existing institutional violence, arrest leaders of the (political and social) opposition, and exacerbate the plight of human rights and anti-democratic tendencies within a country (Table 1; CIIS, 2017; IIAS, 2019).

These have often been construed as Chinese efforts to externalize the standards to support its domestic model of digital/cyber governance (or surveillance), which President Xi Jinping stated during the $19^{\text {th }}$ Party Congress as an alternative governance 
model provided by China the new governance model. China reportedly held training sessions for country representatives on new media and information management, whose effects already exist. Tanzania and Uganda have passed restrictive laws on online media; Zambia is considering the adoption of certain China-influenced standards on censorship that could limit some forms of freedom of expression to achieve greater social stability. Kenya has passed the Computer Misuse and Cybercrimes Act, with serious limitations on freedom of speech (Chellaney, 2017; BRI 2019; Kliman et al., 2019, pp. 24-25).

An increasing number of scholarly and policy-related literature has validated the loopholes and issues of the BRI-related projects (IIAS, 2019). The political situation in countries like Asia and Africa has deteriorated, and the project invariably conflicts with sovereignty claims of many countries in the region, either land or maritime ( $\mathrm{Li}, 2018$; Men, 2019; Du, 2021; Reghunadhan, 2019). According to Li (2018), "Pakistan's internal political bickering" will adversely affect the construction activities in CPEC, an important lynchpin of Chinese activities under BRI. The recent case of Afghanistan has become more of a concern to the BRI project due to the turmoil accompanied by the emergence of the Taliban, and other factions that are part of the in-fighting (Du, 2021) and the potential spillover can have on China's Muslim communities. This includes political turbulence, bottlenecks to economic developments and security lapses within the society (Li, 2018; Reghunadhan, 2019).

Further, Chinese investments are affected due to the internal in countries it is investing as well. Singh (2019), Reghunadhan (2019), Khor et al. (2021), Shaikh \& Chen (2021) have examined how the countries involved in BRI have rising debt levels and is a major problem of BRI-related projects. The criticism of "unsustainable debt burden" caused by BRI on its host member states are but creating narratives of "debttrap diplomacy", "predatory economics," which many scholars have linked to new forms and/or nature of digital and neo-colonialism or economic imperialism towards countries part of the BRI (Ding et al., 2021; Gravett, 2020; McGregor, 2018; Larmer, 2017). Ning (2020) points out the inherent inequalities in bilateral economic relations between China and these debtor nations, the lack of employment opportunities, and economic backwardness in the societies create huge imbalances and problems with projects related to BRI. The security flare-ups in the Af-Pak region have "a spillover effect for the entire South Asian region," deteriorating with the vacuum being created 
with the further withdrawal of US armed forces and the rise of Taliban in the region (Ning, 2020).

Du (2021) bring out issues of the peace process in Afghanistan, while Reghunadhan (2019) has examined the rising threat to CPEC from extremist forces, which are a serious cause of concern for China. Ning (2020) argues as creating 'debtanxiety" on future Chinese investments, increasing losses for investors and affecting the credibility of BRI in the process. China-based Global Times reported that many countries are unhappy with the economic structuring of BRI, with some even looking for loan-waivers from China (Global Times, 2018). Internationally, many scholarly and journalistic literature have come out critically arguing about China's dubious practices, and its negative impact on local countries. Chellaney (2017) has extensively written on the debt trap diplomacy, entailing what is considered and described as forcing countries to "becoming saddled with debt". In October 2017, the US Secretary of Defence James Mattis stated that:

OBOR strategy seeks to secure China's control over both the continental and maritime interests... of dominating Eurasia and exploiting natural resources... that are certainly at odds with US policy. [In] a globalized world, there are many belts and many roads, and no one nation should put itself into a position of dictating OBOR (US Senate Committee on Armed Services 2017, p. 61).

Besides, various countries have pointed out how the project goes through disputed territory, which contradicts the Chinese position and idea of respecting the sovereignty of other countries and not intervening in the internal matters of other countries. The US considers that the aggressive position of China in the South China Sea does set shape the possibilities of future nature of Chinese actions on a global scale after BRI has been globally institutionalized (Ibid., pp. 62-91). There are increasing possibilities of backlash in the Asia-Pacific region, increasing resistance against various projects mainly by the local public, and concern for investments in Sri Lanka, Maldives, and Malaysia. The increasing issues of corrupt practices of politicians in the office with Chinese SoEs creating financial and environmental implications for projects. It has, in turn, challenged the Westphalian norm of sovereignty through multi-decade long infrastructural projects through the disputed territory of other countries, increased opaqueness (or lack of transparency) via bidding processes, accountability and scrutiny, and increased geopolitical risks as well as vulnerabilities (Kliman et al., 2019). 


\section{Conclusion}

The world is moving towards a transformation that sees an acceleration in multipolar and multistakeholderism through fragmented digitalization, which has seen it remould itself with Chinese characteristics. Investment and technological connectivity have been part of the BRI project, which saw the rise in countries' strategic (re)positioning worldwide. As examined in the study, it was found that there occurs a transformational and transitional aspect of STI diplomacy of PRC across nations part of this international project, which often is construed with features of extended regionalism. This is adherent to the (re)construction of the new developmental state's ideational, conceptual and epistemological aspects. This, according to the study, has (re)created and transpositions STI diplomacy in the modern era.

Being developed in a broader political, social and economic environment, differentiated and diversified due to the nature of emerging digital ecosystems, this is inherently diagonal, often contradicting the established ideals and norms of the West. With the rise and institutionalization of the STI diplomacy in BRI within the framework of the 'new developmental state' moulded in the overarching nature of PRC's image, it has often been constructed, construed and problematized as an issue, which projects and legitimizes the values and norms of the Chinese society, right or wrong, into the host countries being part of the BRI. This has largely influenced, institutionalized and legitimized the China model of STI diplomacy through the BRI initiative, within the context (as well as emergence) of the state capitalism, in the BRI-host countries, as well as across the world. PRC's role as a major stakeholder in the global STI diplomacy has thus been increasing, particularly evident of the various projects undertaken in the BRIhost countries in the field of digital infrastructure, surveillance systems, Smart (or Safe Cities), innovation centers, AI, cyber policing, scientific and technical cooperation, big data as well as R\&D in other emergent and frontier technologies.

An important facet and issue that has emerged with the increasing involvement of Chinese features in these countries have been surveillance and authoritarianism-related features. Interestingly, Chinese adherence to sovereignty and security for internal/domestic affairs has contradicted its involvement in projects like the CPEC 
being established through disputed territories like that of countries like India. Moreover, the establishment of new institutions like the AIIB has been considered the Chinese way of establishing an alternative system to the Bretton Woods institutions, which can pave the way to international norms and ideational understandings with Chinese characteristics and cultural values. This has its pros and cons, though it has led to a global institutionalization and governance of STI, with the possibilities of greater involvement from China and its trading partners. Despite all the issues and problems associated with the BRI project and the STI diplomacy undertaken by the PRC, it is clear that the world is moving towards a new development model, with the PRC-led STI model at the centre.

\section{References}

1. African Development Bank (2021). African Economic Outlook 2021. Abidjan, Côte d'Ivoire: African Development Bank Group.

2. Aghion, P., David, P.A. \& Foray, D. (2008). Science, Technology and Innovation for Economic Growth: Linking Policy Research and Practice in 'Stig Systems'. Research Policy, Vol. 38(4), pp. 681-693.

3. Amsden, A. (1989). Asia's Next Giant: South Korea and Late Industrialization. New York: Oxford University Press.

4. Antons, C. (2003). Law and Development in East and Southeast Asia. London: RoutledgeCurzon.

5. Appelbaum, R.P., Cao, C., Xueying, H., Parker, R. \& Simon, D. (2018). Innovation in China: Challenging the Global Science and Technology System. Cambridge: Polity Press.

6. Asian Development Bank (ADB). (2021). China, People's Republic of: Study of the Belt and Road Initiative. https://www.adb.org/projects/50141-001/main

7. Banton, C. (2020). Neoclassical Growth Theory. Investopedia. Retrieved from https://www.investopedia.com/terms/n/neoclassical-growth-theory.asp (accessed on 21 August 2020).

8. Belt and Road Initiative (BRI). (2019). Home, https://www.beltroad-initiative.com/ 
9. Calder, K.E. (1993). Strategic Capitalism: Private Business and Public Purpose in Japanese Industrial Finance. Princeton: Princeton University Press.

10. Chellaney, B. (2017). China's Debt-Trap Diplomacy, Project Syndicate, https://www.project-syndicate.org/commentary/china-one-belt-one-road-loansdebt-by-brahma-chellaney-2017-01?barrier=accesspaylog

11. China Institute of International Studies (CIIS) (2017). The Belt and Road Initiative's Opportunities and Risks in South Asia (一带一路”倡议在南亚的机遇与风险). http://images.china.cn/gyw/CIIS-\%E7\%AC\%AC17\%E6\%9C\%9F-\%E2\%80\%9C \%Е4\%B8\%80\%Е5\%B8\%A6\%E4\%B8\%80\%E8\%B7\%AF\%E2\%80\%9D\%E5\%8 0\%A1\%E8\%AE\%AE\%E5\%9C\%A8\%E5\%8D\%97\%E4\%BA\%9A\%Е7\%9A\%84 \%Е6\%9C\%BA\%E9\%81\%87\%E4\%B8\%8E\%E9\%A3\%8E\%E9\%99\%A9.pdf

12. China-Pakistan Economic Corridor (CPEC) (2019). Home, http://cpec.gov.pk/index

13. Chu, Y. (2009). Eclipse or reconfigured? South Korea's developmental state and challenges of the global knowledge economy. Economy and Society, Vol. 38, pp. 278-303.

14. Clairmonte, F. (1959). Friedrich List and the Historical Concept of Balanced Growth. Indian Economic Review, Vol. 4(3), pp. 24-44.

15. Derudder, B., Liu, X. \& Kunaka, C. (2018). Connectivity Along Overland Corridors of the Belt and Road Initiative, Macroeconomics, Trade and Investment Discussion Paper, No. 6, The World Bank, http://documents.worldbank.org/curated/en/264651538637972468/pdf/130490MTI-Discussion-Paper-6-Final.pdf

16. Ding, J., Ratz, C., \& Bergman, M.M. (2021). What Do We See When Looking at China's Engagements in Africa? An Analysis of Mainstream Academic Perspectives. Journal of Contemporary China. [Article in Press].

17. Dixit, A.K. \& Stiglitz, J. (1980). Monopolistic Competition and Optimum Product Diversity. American Economic Review. Vol. 67, pp. 297-308.

18. Du, Z. (2021). Re-analysis of China's Interests in Afghanistan in a Hundred Years of Great Changes (杜哲元：百年大变局下中国在阿富汗的利益再辨析). Open Central Plains Development Research Center. http://www.occri.org.cn/news/shownews.php?lang=cn\&id=149 
19. Elman, B.A. (2005a). A Cultural History of Modern Science in China. Cambridge: Harvard University Press.

20. Elman, B.A. (2005b). On Their Own Terms: Science in China, 1550-1900. Cambridge: Harvard University Press.

21. Fields, K.J. (1995). Enterprise and the State in Korea and Taiwan. Ithaca, New York: Cornell University Press.

22. Gerschenkron, A. (1962). Economic Backwardness in Historical Perspective. Cambridge: Harvard University Press.

23. Global Times (2018). "With declining loaning power, Western countries uneasy as emerging nations step in," http://www.globaltimes.cn/content/1116722.shtml

24. Gravett, W. (2020). Digital neo-colonialism: The Chinese model of Internet and Sovereignty in Africa. African Human Rights Law Journal, Vol. 20(1), pp. 125-146.

25. Helpman, E. (ed.). (1998). General Purpose Technologies and Economic Growth. Cambridge, MA: MIT Press.

26. Hornby, L. (2018). Mahathir Mohamad warns against 'new colonialism' during China visit. Financial Times. https://www.ft.com/content/7566599e-a443-11e88ecf-a7ae1beff35b

27. International Institute for Asian Studies (IIAS). (2019). Belt \& Road Initiative eLibrary, https://iias.asia/research/belt-road-initiative-electronic-library

28. Johnson, C. (1982). MITI and the Japanese Miracle: The Growth of Industrial Policy, 1925-1975. Chicago: Stanford University Press.

29. Judd, K. (1985). On the Performance of Patents. Econometrica, Vol. 53, pp. 567585.

30. Kembayev, Z. (2020). Development of China-Kazakhstan Cooperation. Problems of Post-Communism, Vol. 67(3), pp. 204-216

31. Kennedy, C. (2003). A Patriot's Handbook: Songs, Poems, Stories, and Speeches Celebrating the Land We Love. New York: Grand Central Publishing.

32. Khor, H.O.E.E.E., Poonpatpibul, C., \& Yong Foo, S. (2021). Belt and Road Initiative: A Framework to Address Challenges and Unlock Potential for HighQuality and Inclusive Growth. Singapore Economic Review, Volume 66, Issue 1, pp. $21-58$

33. Kliman, D., Doshi, R., Lee, K. \& Cooper, Z. (April 2019). Grading China's Belt and Road, Center for a New American Security (CNAS), 
https://s3.amazonaws.com/files.cnas.org/CNAS+Report_China+Belt+and+Road_f inal.pdf

34. Kohli, A. (2004). State Directed-Development: Political Power and Industrialization in the Global Periphery. Cambridge: Cambridge University Press.

35. Kor, K.B. (2016). Broken dreams of China's lost generation. Strait Times. https://www.straitstimes.com/asia/east-asia/broken-dreams-of-chinas-lostgeneration (accessed on 1 February 2020).

36. Larmer, B. (2017). Is China the World's New Colonial Power?. The New York Times. https://www.nytimes.com/2017/05/02/magazine/is-china-the-worlds-newcolonial-power.htm

37. Lei, Z. (2017). 3 sea routes planned for Belt \& Road Initiative. The State Council of the PRC. http://english.gov.cn/state_council/ministries/2017/06/21/content_2814756927601 02.htm

38. Li, Q. (2018). The impact of new trends in the situation in South Asia on the advancement of the “Belt and Road Initiative” in South Asia (南亚局势新动向对 “一带一路”在南亚推进的影响). China Institute of International Studies (CIIS), https://www.ciis.org.cn/yjcg/xslw/202007/t20200710_1073.html.

39. List, F. (1841). The National System of Political Economy. New York: Longmans, Green, and Co.

40. Lockhart, A.B.- (2017). China's $\$ 900$ billion New Silk Road. What you need to know. World Economic Forum. https://www.weforum.org/agenda/2017/06/chinanew-silk-road-explainer/

41. McGregor, R. (2018). "Mahathir, China and neo-colonialism," https://asia.nikkei.com/Opinion/Mahathir-China-and-neo-colonialism

42. Men, H. (2019). "One Belt One Road" Research Journal: 2018: "One Belt One Road" construction and Shanghai's actions (“一带一路”研究辑刊：2018：“一带 一路”建设与上海作为). Shanghai: Tongji University Press

43. Ministry of Foreign Affairs of the People's Republic of China (MFA China). (2013). President Xi Jinping Delivers Important Speech and Proposes to Build a Silk Road Economic Belt with Central Asian Countries. 
https://www.fmprc.gov.cn/mfa_eng/topics_665678/xjpfwzysiesgjtfhshzzfh_66568 6/t1076334.shtml

44. Ministry of Foreign Affairs of the People's Republic of China (MFA China). (2019). President Xi Jinping Delivers Important Speech and Proposes to Build a Silk Road Economic Belt with Central Asian Countries, https://www.fmprc.gov.cn/mfa_eng/topics_665678/xjpfwzysiesgjtfhshzzfh_66568 6/t1076334.shtml

45. Naughton, B. (2007). The Chinese Economy. Cambridge: MIT Press.

46. Nelson, R.R. (1959). The simple economics of basic scientific research, Journal of Political Economy, Vol. 67, pp. 297-306.

47. Ning S. (2020). The current situation, substance and impact of Sri Lanka's foreign debt problem (斯里兰卡外债问题现状、实质与影响). China Institute of International Studies

(CIIS). https://m.ciis.org.cn/yjcg/yjcg_xslw/202007/t20200710_1123.html

48. Ong, A. (2006). Neoliberalism as exception: Mutations in citizenship and sovereignty. Durham: Duke University Press.

49. Pekkanen, R. (2004). After the Developmental State: Civil Society in Japan. Journal of East Asian Studies, Vol. 4(3), pp. 363-388.

50. Ray, D. (1998). Development Economics. Princeton, New Jersey: Princeton University Press.

51. Reghunadhan, R. (2018). Political Economy of Digitalisation and (State) Neoliberalism in China with special reference to 'Made in China 2025'. Research in Social Change, Vol. 10(3): pp. 22-43.

52. Reghunadhan, R. (2019). Future 'Gateway' to the India-China Economic Corridor: A Strategic Approach, Strategic Analysis, 43(2), Taylor \& Francis, pp. 160-167.

53. Rolland, N. (2019). A Concise Guide to the Belt and Road Initiative, https://www.nbr.org/publication/a-guide-to-the-belt-and-road-initiative/

54. Romer, P.M. (1990). Endogenous Technological Change, Journal of Political Economy, Vol. 98(5), October, pp. 71-102.

55. Romer, P.M. (2000). Should the Government Subsidize Supply or the Demand in the Market for Scientists and Engineers?, Innovation Policy and the Economy, Vol.1, pp. 221-252. 
56. Shaikh, R. \& Chen, C.-K. (2021). China's Debt Trap in Pakistan? A Case Study of the CPEC Project. South Asia Research

57. Singh, A.G. (2019). "China's 'South Asia Challenge' for the Belt and Road Initiative," Lowy Institute, https://www.lowyinstitute.org/the-interpreter/chinasouth-asia-challenge-belt-and-road-initiative.

58. Skocpol, T. (1985). Bringing the State Back in Strategies of Analysis in Current Research. In Peter Evans, Dietrich Rueschemeyer, and Theda Skocpol, (eds.). Bringing the State Back In. Cambridge, U.K.: Cambridge University Press.

59. Solow, R. (1956). A contribution to the theory of economic growth. Quarterly Journal of Economics. Vol. 70, pp. 65-94.

60. Spence, A.M. (1976). Product Selection, Fixed Costs, and Monopolistic Competition. Review of Economic Studies. Vol. 43, pp. 217-35.

61. Spence, J. (2001). "Introduction to the Cultural Revolution", In: The Search for Modern China. Retrieved from https://fsi-live.s3.us-west-1.amazonaws.com/s3fspublic/CRintro.pdf (accessed on 30 January 2020).

62. The Economic Times. (2017). China to invest $\$ 800$ billion in Belt and Road initiative over next five years. https://economictimes.indiatimes.com/news/international/business/china-toinvest-800-billion-in-belt-and-road-initiative-over-next-fiveyears/articleshow/58656367.cms?from $=\mathrm{mdr}$

63. Todaro, M. \& Smith, S. (2006). Economic Development. New York, NY: Pearson Education Limited.

64. Toynbee, A. (1884). Lectures on the Industrial Revolution in England: Popular Addresses, Notes and Other Fragments. London: Rivingtons,

65. US Senate Committee on Armed Services. (2017). Political and Security Situation in Afghanistan, Washington DC: Alderson Court Reporting, 1-800-FOR-DEPO.

66. Wade, R. (2000). Wheels Within Wheels: Rethinking the Asian Crisis and the Asian Model. Annual Reviews of Political Science, Vol. 16(3), pp. 281-302.

67. Wei, L. (1984). Interflow of Research Achievements, Knowledge and S\&T Personnel. In Rustam Lalkaka and Wu Mingyu (eds.). (1984). Managing Science Policy and Technology Acquisition - Strategies for China and a Changing World. New York: UNFSSTD.

68. White, G. (1984). Developmental States and Socialist Industrialisation in the Third World. Journal of Development Studies, Vol. 21(1): pp. 97-120. 
69. White, G. (ed.). (1988). Developmental states in East Asia. London: Macmillan Press and The Institute of Development Studies.

70. Wilson, D.C.S. (2014). Arnold Toynbee and the Industrial Revolution: The Science of History, Political Economy and the Machine Past. History and Memory, Vol. 26(2), pp. 133-161.

71. Wong, J. (2004). The Adaptive Developmental State in East Asia. Journal of East Asian Studies, Vol. 4, pp. 345-362.

72. Woo, J. (1991). Race to the Swift: State and Finance in Korean Industrialization. New York: Columbia University Press.

73. Woo-Cummings, M. (1999). The Developmental State. Ithaca, New York: Cornell University Press.

74. Xi, J. (2013). Promote Friendship between Our People and Work Together to Build a Bright $\quad$ Future. MFA China. www.fmprc.gov.cn/mfa_eng/wjdt_665385/zyjh_665391/t1078088.shtml

75. Xi, J. (2017). Work Together to Build the Silk Road Economic Belt and The 21st $\begin{array}{lllll}\text { Century } & \text { Maritime } & \text { Silk }\end{array}$ https://www.fmprc.gov.cn/mfa_eng/zxxx_662805/t1465819.shtml 